\title{
THE ANALYSIS SPEECH ACTS OF THE MAIN CHARACTER IN FREEDOM WRITERS MOVIE SCRIPT
}

\author{
Upit Mulyani ${ }^{1}$, Dewi Latifah ${ }^{2}$ \\ ${ }^{1}$ IKIP SILIWANGI \\ 2 IKIP SILIWANGI \\ ${ }^{1}$ upit_mulyani@yahoo.com, ${ }^{2}$ dedewilatifah@gmail.com
}

\begin{abstract}
In the study of language, what people do by saying something is called speech acts. Speech acts are not only found in everyday life but also in the film. This research concerns with speech acts produced by the main character in Freedom Writers movie script. The aims of this research are to describe the types of speech acts and to analyze the most dominant speech acts produced by the main character. Besides, the aims of this research are also to know and describe the purposes of Erin Gruwell as the main character to use speech acts. Austin's (1962) theory of speech acts is applied in this research as the major theory. This research is qualitative research. The subject of this research is texts in the form of movie script and document analysis is used to gather the data. Qualitative research is applied to analyze the data in the form of the text. There are 100 utterances to be analyzed. The result of this research shows that the five types of speech acts produced by Gruwell are representatives, directives, expressives, commissives and declarative. This study shows that the dominant speech acts used is representatives and it reaches 58\%. It indicates that Gruwell uses representative because she wants to express what she really knows.
\end{abstract}

Keywords: representative, Erin Gruwell, speech acts

\section{INTRODUCTION}

Communication is usually represented by the utterances of the speakers. In attempting to express themselves, people do not only produce utterance containing grammatical structure and words, but also they perform action via those utterance. It shows that every word, phrase or sentence that is human uttered perform different implicit action or meaning in it and if the hearer cannot get the intention of every utterance, it will lead a misunderstanding.

Common people make communication unstructured, it does not become problem because the most important of that is their speech can be understood and accepted by others. Language reflects not only in oral communication, but also in written, such as in magazine, newspaper, letters and others kinds includes manuscript on some document in movie or history. Many people like watching movie but according to the researcher not all of people undestand about the form or the function of language that used there. Sometimes people do not care about the form or the function of communication used in the movie. Common people believe that the important is interesting story or not, or they watch film because of the actors or actrees who plays in that movie.

Pragmatics is the study of the relationships between linguistic forms and the users of those forms. Pragmatics is closely related terms in language study. Pragmatics refers to meaning contruction in specific international context, it is also cite to the study of meaning in use or 
meaning interaction (Mullany \& Stockwell, 2010). In other words, pragmatics focuses on the meaning of their communication. Pragmatics studies meaning in relation to speech situation (Leech, 1983).

Others in sociolinguistics, it more studies about the implication between the languages itself with the impact to society. (Holmes, 1992) writes that sociolinguistics learns about the relationship between language and society. They are interested in explaining why we speak differently in different social context and the social function of language and also the social meaning. Both of pragmatic and sociolinguistic concern on linguistic meaning as determined in a speech community, which includes the linguistic act that involved speech act as the basic of linguistic communication (Searle, 1969).

On any occasion, speech acts usually perform an action. An action performed produces an utterance, which consists of three aspects of acts (Yule, 1996), which can be seen in the examples of Austin's categorization of speech acts as follows: (a) Locutionary act is "what is said" in the form of utterance that is the act of saying something. If someone says ; knock the door! "ee the locutionary act is the realization of the speaker"es utterance. (b) Illocutionary act is "what is done in uttering the word", the function of the word, and the specific purpose of the speaker's mind. The utterance "I swear to give it back next time" is used to perform the illocutionary act of promising. (c) Perlocutionary act is "what is done by uttering the word" which is actually the effect on listener's reaction. The utterance "there is something in your shoulder!" may cause the listener to panic and to look on his shoulder. Thus, this perlocution is to cause those emotion and action of the hearer.

There are five types of classification speech acts by (Yule, 1996), there are representative, expressive, directive, commissive and declarative. Representatives are those kinds of speech acts that state what the speaker believes to be the case or not. Expressives are those kinds of speech acts that state what the speaker feels. Directives are kinds of speech acts that the speakers use to get someone else to do something. Commissives are those commit themselves to some future course of action. Based on the theory of (Rogers, Wall, \& Murphy, n.d.) declarative is like excommunicate, appoint, declare, christen as well as some uses of suggest, state, insist, in formalized setting, bring into reality some new state of affairs noted in the proportional content of declarative.

To be able to gain the types of speech act, the researcher needs to find one of oral or written communication whether they are monolog or dialog. Conversation is one of the sources of getting types of speech act because through conversation, the researcher may gain many utterances, which are not directly spoken to the listener so that the researcher needs to analyze those utterances into a target meaning. By doing so, it means that the researcher needs to analyze to understand a deep meaning of what is said by the speaker. The conversation in the movie can be a good example of speech acts because it represents the complex case of speech acts in order to find out what the main character do by saying something. In this case, a scrpit of a movie is an essential part in a movie because the script contains the dialogues spoken by the characters on the film.

Speech acts is the study which deals with how to do things with words. Related to the Austin's theory of speech acts and three elements of act utterences above, this research analyzes speech acts of the main character in Freedom Writer movie script. This movie was released in 2007 by Erin Gruwell, well the main character in this movie is Erin Gruwell as a teacher in one of secondary school at California, USA. Erin Gruwell's chosen in this research because she has a 
communicative purposes expressed in his utterences. This study uses movie script as the object of the research.

Therefore, the researcher looks for and analyzes the speech act from the "Freedom Writers Movie" script. The writer gave this research title is "THE ANALYSIS SPEECH ACTS OF THE MAIN CHARACTER IN FREEDOM WRITERS MOVIE SCRIPT".

1. What types of speech acts are found in Freedom Writers movie script produced by the main character?

2. Which are the most dominant speech acts frequently used by the main character in Freedom Writers movie?

Concerning with the problem to discuss, this research has two goals. They are :

1. To describe the types of speech acts which are produced by the main characters in Freedom Writers movie script.

To explain and analyze the most dominant speech acts produced by the main characters in

Freedom Writers movie script.

\section{RESEARCH METHOD}

This study was analyzed naturally every single speech acts occur based on the theories of speech acts proposed by (Yule, 1996) in his theory of types of speech acts, and (Searle, 1969) in his theory of the classification of types of speech acts into representative, directive, commissive, expressive, and declaration.

Qualitative research is applied to analyze the data in the form of the text in the movie script. Furthermore, the technique of data collection in this research is documentary study. This research applies a documentary study because the data is in the form of document or written text. (Denscombe, 2007) argues that "documents can be obtained from the internet such as website pages, home pages, or email and they can be treated like online documents". In this study, the data are taken from the official website of movie script www.script-orama.com. There are 409 utterances produced by the main character in Freedom Writers movie script. Here, simple random sampling is used as a sampling strategy in this study to choose the utterances of the main character randomly. In this case, there are only 100 utterances of the total number of utterances that will be analysed.

In this research, descriptive, statistical, and interpretative techniques are used as the technique of the data analysis. The descriptive technique is used to analyse the speech acts produced by the main character in Freedom Writers movie script by applying the theory of speech acts proposed by Austin. After that, the statistical method is used to classify and count the utterances produced by the main character to know the percentage of the most dominant speech acts used. Last, the interpretative method is used to interpret the purposes of the main character using speech acts according to Searle's theory of the types of speech acts and the context of situation theory proposed by Halliday. Later, the findings are discussed by relating those findings tothe goals of the study. Last, the conclusions of the study are drawn.

\section{RESULTS AND DISCUSSION}

\section{Results}

\begin{tabular}{|l|l|l|l|}
\hline Rank & $\begin{array}{l}\text { The types } \\
\text { of speech } \\
\text { acts }\end{array}$ & Quantity & Percentage \\
\hline
\end{tabular}




\begin{tabular}{|l|l|l|l|}
\hline 1 & $\begin{array}{l}\text { Representa } \\
\text { tive }\end{array}$ & 58 & $58.00 \%$ \\
\hline 2 & Expressive & 15 & $15.00 \%$ \\
\hline 3 & Directive & 15 & $15.00 \%$ \\
\hline 4 & $\begin{array}{l}\text { Commissi } \\
\text { ve }\end{array}$ & 10 & $10.00 \%$ \\
\hline 5 & $\begin{array}{l}\text { Declarativ } \\
\text { e }\end{array}$ & 2 & $2 \%$ \\
\hline & Total & 100 & $100.00 \%$ \\
\hline
\end{tabular}

This table shows the percentage of types of speech acts used by Erin Gruwell. The result of the analysis of speech acts shows that the highest of speech acts produced by Erin Gruwell is Representatives, 58\%. Expressives, directives and commissives respectively follow representatives with the percentage $15 \%, 15 \%$ and $10 \%$. The lowest speech acts is directives with the percentage $2 \%$.

\section{Discussions}

The result of the analysis shows that Gruwell in the movie tends to use five types of speech acts. They are representatives, expressive, directive, commissives and also declarative.

\section{Representative}

Representatives are also found in this analysis because Gruwell also tries to represent a situation or condition which can be assumed as truth or falsity. It consists of 29 utterances of asserting, 11 utterances of stating, 9 utterance of concluding, and 9 utterance of informing. (Yule, 1996) explained that representatives are those kinds of speech acts that state what the speaker believes to be the case or not. Gruwell uses representatives to represent a situation or condition that can be assumed as a truth or falsity. In this case, the most dominant act uses by Gruwell is asserting form. Gruwell uses asserting to emphasize to the truth of expressed proposition. From the analysis, I find that Gruwell uses some acts that belong to representatives are to state or express his beliefs and the truth.

\section{Expressive}

Expressives are also found in this analysis. Gruwell uses expressives in order to represent psychological expression. Gruwell uses this kind of speech acts to state what she really feels. In addition (Yule, 1996) argued that expressive are those kinds of speech acts that state what the speaker feels. In this movie, Gruwell uses some kinds of acts that belong to expressive. There are 15 utterances that belong to expressive. It consists of 4 utterances belonging to the expression of disappointment, 2 utterances belonging to the expression of fury, 5 utterance of protesting, 1 utterance of dislike, 1 utterance belonging to the expression of indifference, 1 utterance of sharing, and 1 utterance of apologizing.

Gruwell uses expressive form to represent his psychological expression. Related to the story, she expresses his feelings to Scott who knows there is a problem with Gruwell. Scott knows that Gruwell actually is against herself to face the kind of students characters. Gruwell tries to explain that she is like her job as a teacher. Here, Gruwell explains what she really feels when she sees the students. Gruwell tells all of his feeling to Scott and her father. It can be concluded that Gruwell uses expressive to represent her feelings or his emotions. 


\section{Directives}

The analysis illustrates that Gruwell in the movie tends to use directives than the other types of speech acts. According to (Yule, 1996) that directives are kinds of speech acts that the speakers use to get someone else to do something. In this case, Gruwell uses a variety of acts that belong to directives. They are 1 utterances of warning, 2 utterances of ordering, 3 utterances of asking, 2 utterances of allusion, 3 utterance of supporting, 1 utterance of reminding, 1 utterance of offering, 1 utterance of agreeing, and 1 utterance of forbidding. People do not use language just to state things but to do things, and to perform actions (Thomas, 1995).

Related the story, Gruwell tends to use directives because she wants to make the hearer do something. Gruwell uses this kind of acts because she wants to express what she really wants. The analysis finds that Gruwell uses some act of supporting more often than other acts because Gruwell has a trouble with her students.

\section{Commissives}

(Yule, 1996) stated that commissives are those commit themselves to some future course of action. In this case, Gruwell uses these kinds of speech acts because she wants to perform an action in the future. It consists of 6 utterances of threatening, 6 utterances of promising, and 3 utterance of refusing. Therefore, the total number of commisives is 15 utterances.

Gruwell uses commissives to commit the speaker to some future course of action and express what the speaker intends. Gruwell uses an act of threatening more often. In this case, Gruwell uses commissives because she wants to perform an action in the future. Gruwell uses the act of threatening to show that she is a teacher who can changes her students before in darkness to the brightness, because the students had a problem of their environment from the past.

\section{Declarative}

The least speech acts is declarative, from this movie the researcher can not found out more of declarative. In this case Gruwell uses this speech acts becuase she want to students make a change in their life.

From the proportion of five classifications of illocutionary speech acts, the researcher concluds that representatives were the most dominant types of illocutionary speech acts because the speakers, Erin Gruwell tented to deliver her spoken to the truth of some expressed proposition by asserting, concluding, claiming, hypothesizing, telling and etc. Then the least ones of those fives classification of illocutionary acts was declarative. Based on the theory of (Searle, 1969), five classifications of illocutionary acts stated that declarative is like excommunicate, appoint, declare, christen as well as some uses of suggest, state, insist, in formalized setting, bring into reality some new state of affairs noted in the proportional content of declarative.

\section{ACKNOWLEDGMENTS}

The writers would like to thanks to PROJECT (Professional Journal of English Education) IKIP Siliwangi Bandung who has given the writers chance to publish this article.

\section{CONCLUSION}

Based on the analysis and the results, it can be concluded that the main character used five kinds of speech acts. The five speech acts that is used are representatives, expressive, directives, commissives and declarative. 
Besides, the researcher also finds that the most dominant speech acts that is used by the main character in Freedom Writers movie script. It is found that the most dominant speech acts used is Representative. There are 58 utterances from 100 utterances that belong to representative. It is about $58 \%$ of the total percentage of the utterances. It means that the main character often produces representative than the other speech acts.

The analysis shows that the purposes of Gruwell as the main character using speech acts are various according to what types of speech acts she produces. It also relates to the story in the movie. From the analysis, it is found that Gruwell tends to use representative because she wants to express what she really knows. The purpose why Gruwell uses representatives because she wants to represent a situation or condition that can be assumed as truth or falsity. Related to the story, Gruwell uses asserting act to state all about improvement her students. She wants to state that she can teach her students with her approach.

Finally, the researcher hopes that this research will give a contribution to the readers a better understanding of speech acts, and can be an additional reference for those who are interested in learning more about speech acts and also in making further study on similar topic. The researcher hopes that other researchers will be able to continue this study in order to enrich pragmatics researches.

\section{REFERENCE}

Denscombe, M. (2007). The Good Research Guide : For Small-Scale Social Research Projects. New York: Open University Press.

Holmes, J. (1992). An Introduction to Sociolinguistics.

Leech, N. G. (1983). Principles of Pragmatics.

Mullany, L., \& Stockwell, P. (2010). Introduction English Language. New York.

Rogers, A., Wall, B., \& Murphy, J. (n.d.). A Classification of Illocutionary acts. In Proceedings of the Texas Conference on Performatives, Presuppositions \& Implicatures. Washington D.C: Centre For Applied Linguistic.

Searle, J. R. (1969). Speech Act: An Essay in The Philosophy of Language. Cambridge University Press.

Thomas, J. (1995). Meaning in Interaction : An Introduction to Pragmatics.

Yule, G. (1996). Pragmatics. Oxford University Press. 